\title{
HAKEKAT RITUAL IBADAH HAJI DAN MAKNANYA BERDASARKAN PEMIKIRAN WILLIAM R. ROFF
}

\author{
Azalia Mutammimatul Khusna \\ Universitas Islam Negeri Sunan Kalijaga Yogyakarta \\ Email : husnakamila046@gmail.com
}

\begin{abstract}
Abstrak : "The Pilgrimage is one of five pillars of Islam which must be done by the followers of this religion, and this ritual is only done by who are capable to do it. In Indonesia, the Moslems will go to do the pilgrimage after walk on some rituals before hajj or pilgrimage with the faith that these rituals give the fluency to the doers. Of course, as Indonesia has many cultures, the ritual before doing pilgrimage is different each others and these differences don't mean give the different quality in their worships to God Allah and their reward. The implementation of Pilgrimage, according to the writer, is the regular worships to bring near the God with some gestures and all of them contain everything that make us remember to the power of Allah. William R. Roff, in the book of Richard C Martin (2010), said that the rituals of Pilgrimage is the symbols of Moslems life whicheas these symbols are the way for human to upgrade their believes after inspiring the meaning of these symbols."
\end{abstract}

Kata kunci : Islam; Pilgrimage; Rituals; The Meanings; Symbols

\section{A. PENDAhULUAN}

\section{Latar Belakang Masalah}

Islam merupakan agama yang paling banyak pemeluknya di sebagian besar belahan dunia. Agama ini menjadi daya tarik tersendiri bagi para peneliti dan sejarawan untuk dikaji dan diteliti hakikatnya, ritual-ritualnya dan hal-hal lain yang terdapat didalamnya. Islam sendiri memberi ketenangan rohani bagi pemeluknya dalam setiap pelaksaan ibadah atau ritual keagamaan. 
Haji termasuk dalam rukun Islam, rukun Islam sendiri merupakan simbol bahwa seorang muslim benar-benar menjadi muslim ketika dia menjalankan kelima rukun ini dan menghayati makna-maknanya, serta menearpkan apa yang mereka hayati itu dalam kehidupan sehari-hari. Dalam pelaksanaannya di Indonesia, orang yang ingin berangkat haji biasanya melakukan ritual-ritual atau menjalani adat tertentu yang diyakini dapat menambah kekhusyuan dan kelancaran ketika melaksanakan ibadah haji.

Pelaksanaan ibadah Haji, menurut penulis sendiri adalah sebuah rutinitas mendekatkan diri kepada Allah dengan berbagai gerakan yang semuanya mengandung hal-hal yang mengingatkan kita pada kekuasaan Allah. William R. Roff, dalam bukunya Richard C. Martin (2010), berpendapat bahwa ritual dalam ibadah haji merupakan simbol kehidupan seorang muslim dimana simbol tersebut merupakan cara manusia menambah keimanannya setelah menghayati arti dari simbol-simbol tersebut.

Dengan adanya pendapat William R. Roff ini, seyogyanya hal tersebut menjadi acuan dan contoh bagi para peneliti dan sejarawan untuk mengkaji tentang Islam dan simbol-simbol yang ada dalam setiap ritual keagamaan, karena dia menjelaskan dengan gamblang tentang metode yang bisa digunakan dalam penelitian suatu agama.

Dibawah ini, penulis akan menjelaskan tentang pandangan William R. Roff khususnya dalam memaknai ibadah haji.

\section{Telaah Pustaka.}

Sebelumnya, pemaknaan dan analisis tentang ibadah haji ini juga banyak dijelaskan dalam berbagai karangan, salah satunya dalam buku Al Islam milik Said Hawwa yang sudah diterjemahkan ke dalam bahasa Indonesia. Buku ini menjelaskan tentang Islam dan makna ritual yang ada didalamnya. Penjelasan-penjelasan tersebut sangatlah berkaitan dengan kajian terhadap haji secara teoritis yang dikemukakan oleh William R. Roff.

Said Hawwa juga menberikan tinjauan analisis ibadah haji secara gamblang dan jelas. Menurutnya, haji merupakan sejumlah simbol yang terbentuk dari berbagai amalan, simbol penyerahan manusia kepada Allah, maksudnya adalah ritual-ritual yang ada dalam ibadah haji dimaknai sebagai cara untuk mendekatkan diri kepada 
Allah melalui serangkaian tata cara atau urutan pelaksanaan. Said juga menjelaskan bahwa haji adalah simbol persatuan ummat Islam, tanpa memandang ras, warna kulit dan kebangsaan, karena dasar persatuan kaum Musliminadalah aqidah, agama dan syari'at Islam, sehingga umat ini tak lagi melihat hikmah dan maknanya, melainkan penyerahan tanpa syarat kepada perintah Allah. ${ }^{1}$

Dia juga menyebutkan bahwa dengan haji, seseorang belajar selalu hidup dalam suasana ibadah, dia juga belajar bersikap ramah dan memberikan kasih sayang kepada setiap mukmin (orang beriman). Seorang muslim juga belajar mengendalikan emosi dan melatih kesabaran serta gejolak nafsunya, ia memahami hakikat ibadah kepada Allah, belajar hidup keras dan menghadapi berbagai kesulitan, membangun loyalitas kepada orang-orang yang dicintai Allah serta memusuhi orang-orang yang menjadi musuh Allah. Pelajaran-pelajaran yang didapat dalam ibadah haji ini sangatlah banyak disebutkan dalam buku Al Islam.

Kemudian dalam rukun-rukun haji yang terdapat dalam ibadah haji juga bisa disimbolkan dan dimaknai secara filosofis. Adapun pemaknaan symbol-simbol tersebut akan dijelaskan dalam artikel berikut ini.

\section{Permasalahan.}

Kajian terhadap hakekat haji, symbol dan maknanya memiliki beberapa permasalahan, seperti:

a. Bagaimana pemaknaan ibadah haji menurut William R. Roff yang merupakan seorang orientalis?

b. Apa dampak pelaksanaan ibadah haji dalam kehidupan sosial?

\section{Metodologi.}

Dalam penelitiannya, William R. Roff menggunakan metode fenomenologi yang juga digunakan oleh Arvind Sharma dalam kajiannya. Arvind Sharma adalah salah seorang sarjana yang mencoba mendefinisikan metode fenomenologi dengan menganalisis definisi-definisi yang diusulkan oleh Brede Kristensen (1867-1953) dan Gerardus van der Leeuw (1890-1950).

\footnotetext{
${ }^{1}$ Hawwa, Said, Al Islam Jilid 1 (Diterjemahkan oleh Abu Ridho dan Aunur Rofiq Shaleh Tamhid, Lc.), (Jakarta: Al I'tishom Cahaya Umat, 2012), hlm. 307
} 
Dari kajiannya, Sharma mendefinisikan bahwa "fenomenologi agama adalah suatu metode kajian agama yang ditandai dengan upaya mencari struktur yang mengarisbawahi data keagamaan yang dapat diperbandingkan sehingga tidak menyalahi pemahaman orang-orang beriman itu sendiri”. ${ }^{2}$

Selain menggunakan metode fenomenologi, William juga menggunakan metode Liminalitas atau Transisi yang disandarkan pada pendapat Victor Turner dalam memaknai seluruh proses ibadah haji. ${ }^{3}$

Kemudian untuk mendeskripsikan pemikiran William R. Roff, penulis menggunakan metode kualitatif deskriptif yang berarti mendeskripsikan hasil dari penelitian dengan uraian-uraian kalimat yang jelas dan dapat memberikan pemahaman bagi pembaca.

\section{B. HASIL DAN PEMBAHASAN}

\section{Pengertian Haji.}

Haji, perjalanan ibadah ke Mekkah - atau lebih tepat, seperangkat ibadah yang ditunaikan disana dalam periode waktu yang telah ditentukan, seperti yang sudah dilakukan Muslim sejak tahun $10 \mathrm{H}$ (632 M) atau mungkin sebelumnya. Ketika haji untuk pertama kalinya dinyatakan sebagai salah satu kewajiban yang harus ditunaikan seorang Muslim setidaknya sekali semasa akil balighnya, seperti firman Allah dalam Surat Ali Imran ayat 91 yang berbunyi:

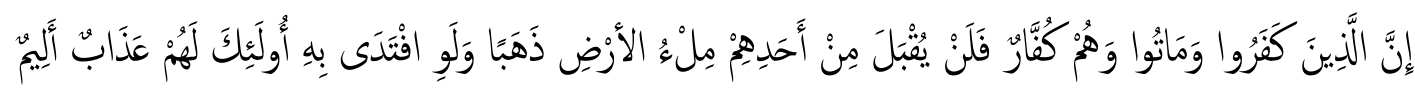

$$
\begin{aligned}
& \text { وَمَا لَهَمْ مِنْ نَاصِرِينَ (91) }
\end{aligned}
$$

Artinya: "Sesungguhnya orang-orang yang kafir dan mati dalam kekafiran, maka tidak akan diterima (tebusan) dari seseorang di antara mereka sekalipun berupa emas sepenuh bumi, sekalipun dia hendak menebus diri dengannya[19]. Mereka itulah orang-orang yang mendapat siksa yang pedih dan mereka tidak memperoleh penolong."

\footnotetext{
${ }^{2}$ Zakiyuddin Baidhawy, "Islamic Studies: Pendekatan dan Metode" pdf, (Yogyakarta: Insan Madani, 2011), hlm. 278

${ }^{3}$ William R. Roff, "Haji dan Sejarah Agama-Agama” dalam Richard C. Martin, Pendekatan Terhadap Islam dalam Studi Agama (Yogyakarta: Suka Press, 2010), hlm. 93
} 
Dan tak lama kemudian seluruh kaum Muslim yang hidup di kawasan Arabia, mayoritas di Hijaz itu sendiri sejak abad ke $8 \mathrm{M}$, kaum Muslim lebih banyak yang tinggal di luar kawasan Arabia, dan sebagian mereka bahkan tinggal di daerahdaerah yang sangat jauh seperti Spanyol di belahan barat dan Sind di belahan timur. Beberapa abad kemudian, populasi kaum muslim secara substansial sudah berada di seluruh pelosok dunia, dari pojok-pojok yang jauh di belahan Afrika hingga Cina. ${ }^{4}$

Dari pernyataan diatas dapat dikatakan bahwa Islam menyatukan berbagai ras, suku, dan kebangsaan dalam satu wadah peribadatan dan segala proses yang ada didalamnya tanpa memandang adanya perbedaan-perbedaan tersebut.

Pendapat ini sesuai dengan Said Hawwa yang mengatakan bahwa ibadah haji adalah simbol persatuan ummat Islam, tanpa memandang ras, suku, warna kulit dan kebangsaan, karena dasar persatuan kaum muslimin adalah syar'ah dan aqidah Islam. $^{5}$

Muhammad Sholikhin dalam bukunya juga menjelaskan bahwa arti kata "Haji" secara lughawi (bahasa) adalah berziarah, berkunjung atau berwisata suci. Dalam istilah fiqh, haji memiliki makna perjalanan seseorang ke Ka'bah guna menjalankan ritual-ritual ibadah haji dengan cara dan waktu yang telah ditentukan (Sulaiman Al Bijairami, Hasyiah Al Bujairami Ala- Al Minhaj 6/10). ${ }^{6}$

Menurut Imam Asy-Syafi'i, bulan-bulan haji adalah Syawal, Dzulqa'dah, dan 10 hari pada permulaan Dzulhijjah. Dalam arti, niat haji seseorang harus ada di bulan-bulan tersebut. Pekerjaan yang diniatinya menjadi ibadah umrah jika tidak dalam bulan itu. Tempat pelaksanaan Haji adalah Mekkah, Arafah, Mina dan Muzdalifah yang semuanya berada dalam kawasan Al Masy'ar Al Haraam. Disebut demikian karena tempat ini penuh dengan mercusuar kesucian Ilahi. Ritualnya dimulai saat miqat, ihram selama haji berlangsung, tawaf di Baitullah, sa'i diantara bukit Shafa dan Marwah, wukuf di Arafah, mabit (bermalam) di Mina dan Muzdalifah, melontar jumrah di Mina, dan tahallul di akhirnya. Kewajiban haji ini

\footnotetext{
${ }^{4}$ William R. Roff, “Haji dan Sejarah Agama-Agama” hlm. 87

${ }^{5}$ Hawwa, Said, Al Islam Jilid 1 (Diterjemahkan oleh Abu Ridho dan Aunur Rofiq Shaleh Tamhid, Lc.), (Jakarta: Al I'tishom Cahaya Umat, 2012), hlm. 307

${ }^{6}$ Muhammad Sholikhin, Keajaiban Haji dan Umrah: Mengungkap Kedahsyatan Pesona Ka'bah dan Tanah Suci (Jakarta: Erlangga, 2013), hlm. 2
} 
hanya sekali seumur hidup, sedangkan haji yang kedua, ketiga dan seterusnya merupakan sunnah. ${ }^{7}$

\section{Rangkaian Ritual Ibadah Haji dan Maknanya.}

Dalam penelitiannya, William R. Roff menganut pandangan Arnold van Gennep tentang serangkaian ritus keagamaan yang disebutnya rites de passage, yang merupakan suatu kerangka untuk menuliskan pandangannya tentang serangkaian ritus-ritus tersebut. Dalam tahapannya, haji di reduksi menjadi tiga, yaitu: pra pelaksanaan, pelaksanaan, dan pasca pelaksanaan atau tahap perpisahan. Dia juga mengatakan bahwa pada hakikatnya, perjalanan ke Tanah Suci tidak memainkan peranan penting dalam contoh-contoh mengenai pelaksanaan ibadah haji, namun sangat jelas bahwa penduduk Tanah itu sendiri harus meninggalkan rumahnya untuk memulai haji mereka, tak ada bedanya dengan orang Indonesia yang harus melewati setengah belahan dunia. Maksudnya, ibadah haji haruslah dilakukan di tanah suci meskipun rumah tinggal pelaksananya berada di sekitar Tanah Suci. Dalam konteks ini, ibadah haji melibatkan baik perjalanan teritorial maupun perjalanan simbolik. ${ }^{8}$

Perjalanan teritorial yang dimaksud dalam hal ini, yakni perjalanan melewati berbagai daerah atau begara untuk sampai ke tanah suci, contohnya: perjalanan dari Indonesia ke Makkah. Sedangkan perjalanan simbolik berarti perjalanan keluar dari rumah untuk menuju tanah suci, yang dimaksud adalah penduduk Arab sendiri yang melakukan perjalanan dari rumahnya menuju tanah suci.

Dari perjalanan teritorial inilah Arnold Van Gennep menemukan pandangan yang disebutnya sebagai rites de passage, ia bertitik tolak dari profan, melintasi ambang yang suci dan penggabungan yaitu tahap-tahap pelaksanaan ibadah haji yang akan dikemukakan penulis pada paragraf dibawah.

Sebelum masuk panggung haji ini, manusia lupa kepada persamaan diantara sesama mereka. mereka tercerai berai karena kekuatan, kekayaan, keluarga, tanah, dan ras mereka. kehidupan mereka hanyalah eksistensi semata. Tapi pengalaman haji

\footnotetext{
${ }^{7}$ Muhammad Sholikhin, Keajaiban Haji dan Umrah: Mengungkap Kedahsyatan Pesona Ka'bah dan Tanah Suci, hlm. 3

${ }^{8}$ William R. Roff, “Haji dan Sejarah Agama-Agama” dalam Richard C. Martin, Pendekatan Terhadap Islam dalam Studi Agama (Yogyakarta: Suka Press, 2010), hlm. 88
} 
membuat mereka menemukan diri mereka sendiri yang telah lama hilang dan berpandangan satu, bahwa mereka semua adalah satu dan masing-masing diantara mereka tak lebih dari seorang 'manusia'. 9

Dalam paragraf sebelumnya, telah dikemukakan bahwa William menyebutkan bahwa ibadah haji memiliki tiga tahapan dari kerangka rites de passage, yang akan diuraikan sebagai berikut:

a. Tahap Pra-pelaksanaan.

Bagi kaum muslim yang datang dari jarak tertentu yang jauh, dengan beban keuangan yang cukup berat, dua bulan sebelum Dzulhijjah atau sejak akhir bulan Ramadhan dan seterusnya, mereka mempersiapkan perbekalan yang cukup untuk keberangkatannya menuju tanah suci. Perbekalan tersebut mulai dari keuangan, mental, psikologi, keilmuan dan kesehatan, serta bekal bagi keluarga yang ditinggalkan termasuk pelunasan hutang dan permintaan maaf kepada sanak saudara dan tetangganya atau dengan kata lain seorang calon haji haruslah membereskan segala kewajibannya. Adapun ongkos yang digunakan untuk berhaji haruslah didapat dari cara yang halal, karena Tuhan tidaklah menerima ibadah haji seseorang yang perbekalannya di dapat dari jalan yang tidak halal atau merugikan. Pinjaman yang digunakan untuk ibadah haji pada kebanyakan masyarakat bukan tidak diperbolehkan, tapi dipandang sinis. Diantara persiapan-persiapan ini juga adalah pelunasan segala hutang dan pemberesan segala kewajiban seorang calon haji. ${ }^{10}$

Di Indonesia biasanya calon jemaah haji mengadakan tasyakuran atau menghidangkan makanan kepada tamu undangan, yakni teman, sanak saudara, dan tetangga sebagai bentuk kesyukuran dan permintaan do'a untuk keselamatannya selama melaksanakan ibadah haji. Ada kalanya calon jemaah haji memberikan wasiat-wasiat sebelum keberangkatannya, kalau-kalau dia meninggal di tanah suci. Mereka menyesali semua dosa yang pernah dilakukannya, dengan demikian, sesuatu yang mulanya dianggap sulit dikerjakan akan menjadi mudah.

Perjalanan jamaah haji telah terbentuk menjadi suatu rangkaian ritus keagamaan yang secara bersama-sama membentuk "une premiere etape entre

\footnotetext{
${ }^{9}$ Ali Syari'ati, “Menjadi Manusia Haji” (Yogyakarta: Jalasutra, 2003), hlm. 33

${ }^{10}$ William R. Roff, "Haji dan Sejarah Agama-Agama” dalam Richard C. Martin, Pendekatan Terhadap Islam dalam Studi Agama (Yogyakarta: Suka Press, 2010), hlm. 89
} 
la vie laique et une existence qui va etre de plus en plus voisine du sanctuarie (langkah pertama seorang awam dalam keberadaan yang semakin dekat dengan kehidupan beragama)'”.

Setelah meninggalkan sanak keluarganya, seorang calon haji mulai “comme s'il sortait ce monde (seperti mereka yang meninggalkan dunia ini)”. Sesaat sebelum berangkat, calon haji menunaikan shalat dua reka'at, yang kemudian di ikuti dengan pembacaan ayat-ayat tertentu dari Al Qur'an. Dalam hal ini, ayat yang biasa dibaca adalah ucapan Nabi Nuh sebagaimana dikutip dalam QS.11:41, yang artinya: "Dengan nama Allah, tempat berlayar dan berlabuh". 11

Tahap selanjutnya dalam pra pelaksanaan ibadah haji adalah bila sampai di Makkah, maka yang harus pertama kali dilakukan adalah Miqat, sebagai bagian dari ibadah penyucian diri yang menjadi symbol atau kegiatan menandai tahap akhir usaha meninggalkan kebiasaan lama, dan melepaskan diri secara total dari kaitan-kaitan dan status duniawi dari masa lampau dan dari dosa. Sambil melepaskan pakaian sehari-hari, mencukur rambut dan jenggot serta memotong kuku, mandi besar (ghusl) dan niat melaksanakan ibadah haji, kemudian mengenakan baju ihram, yaitu dua potong kain berwarna putih yang harus digunakan ketika menunaikan ibadah haji.

Mencukur rambut bagi orang yang melaksanakan ibadah haji berarti kerelaannya untuk menanggalkan pikiran-pikiran yang berfokus selain kepada Allah SWT. Dalam hal ini, ibadah haji benar-benar menjadi satu rangkaian ibadah yang dilaksanakan untuk fokus hanya kepada Allah SWT.

Sedangkan kaum wanita diharuskan memakai pakaian putih yang harus menutupi sekujur tubuhnya kecuali muka dan telapak tangan. Dalam situasi demikian, Tuhan tak mempersoalkan masalah derajat, jenis kelamin, atau status bawaan lain selain mereka adalah seorang Muslim yang bersamasama melaksanakan ibadah haji. ${ }^{12}$

Seorang yang berhaji, sebelum memasuki Miqat, yang merupakan titik awal revolusi besar ini, haruslah mengukuhkan niat. Apa saja yang harus dikukuhkan? Yaitu meninggalkan rumah untuk menuju rumah bersama,

\footnotetext{
${ }^{11}$ William R. Roff, "Haji dan Sejarah Agama-Agama” dalam Richard C. Martin, Pendekatan Terhadap Islam dalam Studi Agama (Yogyakarta: Suka Press, 2010), hlm. 90.

${ }^{12}$ Ibid, hlm. 92.
} 
rumah ummat manusia, meninggalkan hidup sehari-hari yang melupakan untuk menggapai cinta, meninggalkan keakuannya untuk berserah diri kepada Allah SWT, meninggalkan penghambaan untuk memperoleh kemerdekaan, meninggalkan diskriminasi rasial untuk mencapai persamaan, ketulusan, dan kebenaran. Meninggalkan pakaian untuk beroleh kesucian, meninggalkan hidup sehari-hari yang fana untuk memperoleh kehidupan yang abadi, dan meninggalkan sikap mementingkan diri sendiri dan hidup yang hampa untuk menjalani kehidupan yang penuh bakti dan tanggungjawab. Intinya adalah peralihan total kedalam keadaan Ihram. Kemudian di Miqat juga seorang calon haji melaksanakan shalat dua rakaat. Dalam shalat ini, dia menghadap Allah sambil berdoa dan berkata bahwasannya ia menghadap Allah sebagai seorang manusia dengan mengenakan pakaian yang sama seperti yang akan dikenakannya ketika menghadap Tuhan. Perkataan ini haruslah dilakukan dengan sesadar-sadarnya dan tulus menaati dan menjadi hamba Allah SWT. ${ }^{13}$

b. Tahap Pelaksanaan

Seperti yang telah disebutkan diatas, setelah usaha untuk meninggalkan kepentingan duniawi yang disimbolkan dalam ritual pra pelaksanaan ibadah haji, para jamaah haji bebas bergerak di segala penjuru kota suci sebagai tamu Allah sambil menyerukan talbiyah.

Pemisahan yang total dari ikatan-ikatan sosial ini menjadi bukti dari apa yang Van Gennep, kemudian Turner lihat sebagai permulaan tahap liminal atau transisi dalam seluruh proses ibadah haji, para jamaah haji telah berubah menjadi "sebagai bayi yang baru lahir dari rahim ibunya". Puncak ibadah haji, yang berlangsung selama beberapa hari, ditandai dengan serangkaian peribadahan yang sentral, esensial yang dilakukan secara bersama-sama, yang sudah sering dipaparkan, yakni: Thawaf, yaitu mengelilingi Ka'bah ketika sampai di Makkah. Sa'i, yaitu berlari-lari kecil antara bukit Safa dan Marwah. Wuquf di padang Arafah. Berkurban di Mina dan melempar batu di Aqabah (jumrah al aqabah). Melempar batu di Aqabah bermakna bahwasannya pelaku ibadah haji siap berjihad dijalan Allah untuk memerangi kebatilan dan kedzaliman, kapanpun dan dalam keadaan apapun.

\footnotetext{
${ }^{13}$ Ali Syari’ati, Menjadi Manusia Haji (Yogyakarta: Jalasutra, 2003), hlm. 35-38
} 
Jika manusia menyadari, haji akan melahirkan gagasan-gagasan Rabbani, peningkatan akhlak islami dan semangat keteladanan yang lebih tinggi terhadap Rasulullah SAW. Contohnya, di Arafah, manusia berkumpul sebelum melaksanakan thawaf rukun. Semua orang yang berniat haji berkumpul disana. Kemudian mereka secara serentak, mereka memulai keberangkatan untuk mengagungkan Ka'bah, kemudian menuju Muzdalifah dalam keadaan telah bertaubat dan berserah diri. Mereka menuju Ka'bah dengan jiwa bersih.

Dari Muzdalifah menuju Mina, untuk melempar jumrah sebagai pernyataan bahwa musuh Allah adalah musuh mereka juga. Kemudian memotong hewan qurban sebagai tanda syukur kepada Allah dan mencukur rambut sebagai persiapan Thawaf dengan hati yang bersih, pakaian yang suci dan penampilan yang bagus.

Setelah thawaf, dilanjutkan dengan $S a^{\prime} i$ yang sebelumnya dilakukan oleh Ibu Hajar yang shalihah pada awal mula baitullah dibangun. Setelah perjalanan ini, manusia menjadi seperti dilahirkan kembali yang kemudian mereka melanjutkan perjalanan ke Mina untuk melontar jumrah sebagai pernyataan permusuhan total terhadap setan untuk selama-lamanya. ${ }^{14}$

Keseluruhan periode inilah yang dicirikan oleh liminalitasnya Turner dilihat dari struktur sosial yang biasa, atau komunitas suatu keterikatan yang muncul secara spontan dan dibangun secara normatif diantara makhluk manusia yang sejajar dan seimbang, bersifat total dan terindividualkan dan lepas dari atribut-atribut struktural.

Pengalaman komunitas ini jelas tampak dalam pelaksanaan haji, dan kandungan ritual dan simboliknya membutuhkan analisis yang paling mendalam didalam terma-terma rites de passege. Dalam hal ini, lebih umum lagi sajian deskriptif tentang haji seperti tawaf yang dilakukan oleh para jamaah haji misalnya, diketahui bahwa tawaf di Ka'bah dan mencium atau menyentuh hajar aswad sebagai ibadah puncaknya. Mereka memperlihatkan kekuatan emosional dan larut dalam satu kesatuan antara seluruh kaum dari seluruh dunia, dari seluruh jenis kulit, status sosial dan kondisi. Mereka

\footnotetext{
${ }^{14}$ Hawwa, Said, Al Islam Jilid 1 (Diterjemahkan oleh Abu Ridho dan Aunur Rofiq Shaleh Tamhid, Lc.), (Jakarta: Al I’tishom Cahaya Umat, 2012), hlm. 308-309.
} 
bersama-sama berdzikir menyebut nama Allah, melantunkan ayat-ayat Al Qur'an, mengucap talbiyah, dan berdoa dengan khusyu'. ${ }^{15}$

c. Tahap Pasca-pelaksanaan.

Setelah serangkaian ibadah tersebut, sampailah para jamaah haji kepada waktu mereka untuk kembali ke tanah kelahiran dan masyarakat masing-masing sebagai individu yang baru, ada yang menjadi semakin baik, ada juga yang sebaliknya.

Tentu saja, dalam penampilan lahiriyah, banyak jamaah haji yang berubah sejak kepulangan mereka dari tanah suci. Mereka bahkan mengganti nama, seakan-akan mengalami lahir kembali. Mereka juga mendapat status baru yang disebut "haji”. Sebagian jamaah haji juga berubah persepsinya tentang Islam dan kaum Muslim, dorongan-dorongannya dan kekuatannya. Seluruh bukti, mulai dari hadis yang awal sampai modern, menunjukkan bahwa haji yang sukses (al-hajj al mabrur), mengandung suatu perubahan. Van Gennep melihat rites de passage sebagai perubahan yang efektif bagi seorang individu dari posisi tertentu sebelumnya ke posisi yang lainnya. Abu Yazid Al Bistami, sebagaimana diriwayatkan oleh al Hujwiri, mengatakan: "Pada perjalanan haji saya yang pertama, saya hanya melihat rumah Tuhan; pada yang kedua, saya melihat rumah Tuhan dengan pemiliknya; dan pada saat yang ketiga, saya hanya melihat Tuhan saja". ${ }^{16}$

Secara normal, manusia yang kembali dari tanah suci hendaknya lebih shalih dan santun dalam sikap serta ucapannya, karena saat berhaji mereka mempelajari nilai-nilai kehidupan yang tak didapatkan sebelumnya. Seperti tidak berkata kasar dan kotor, sebagai wujud dari kebiasaannya ketika haji untuk tidak berkata kotor di tanah suci yang kemudian dibawanya sampai ke masyarakat di tempat asalnya.

Sebagai seorang orientalis, William R. Roff berusaha masuk dalam ritual haji ini dan menempatkan dirinya sebagai objek penelitian sehingga pernyataan-

\footnotetext{
${ }^{15}$ William R. Roff, "Haji dan Sejarah Agama-Agama” dalam Richard C. Martin, Pendekatan Terhadap Islam dalam Studi Agama (Yogyakarta: Suka Press, 2010), hlm 93- 94.

${ }^{16}$ William R. Roff, "Haji dan Sejarah Agama-Agama", hlm 95-96
} 
pernyataan tersebut dinilai masuk akal dan membantu orang lain memahami hakikat haji yang sebenarnya.

Dalam buku Hakikat Islam (Husein, 2008: 162) dijelaskan, perintah haji memang berbeda dengan perintah-perintah ibadah lain dalam Islam. Haji dilakukan hanya karena Allah semata. Haji harus betul-betul dilakukan dengan niat dan motivasi yang murni, 100\% karena Allah, bukan untuk piknik, karena gengsi atau untuk memutihkan dosa dan meminta jabatan, yang kesemuanya itu hanyalah kesenangan duniawi, padahal haji adalah ritual untuk mencapai ketenangan dan kesenangan ukhrowi (akhirat).

Pelanggaran yang paling banyak dilakukan oleh alumni haji adalah akidah dan tauhid, sebagian dari mereka masih terkontaminasi perbuatan kemusyrikan, misalnya masih mendatangi dukun ketika ada barang yang hilang, atau bernadzar di tempat yang dikeramatkan, padahal tujuan utama ibadah haji adalah meyakinkan kembali monoteisme absolut (tauhid murni) yang dicontohkan oleh Ibrahim a.s. Jadi, tujuan utama haji adalah meniru tauhid Ibrahim yang murni, yang akibatnya lahirlah ma'rifatullah yang benar, mengakui eksistensi manusia sebagai hamba, yang dicerminkan dalam pakaian ihram, yang warnanya putih bersih laksana kain kafan, sebagai simbol bahwa manusia akan kembali kepada Tuhan. ${ }^{17}$

\section{Sumbangan dalam Keilmuan (Ilmu-Ilmu Keislaman).}

Penelitian William R. Roff ini memiliki peranan penting dalam memberikan wawasan kepada pembaca baik dari masyarakat awam maupun sarjana tentang Ibadah Haji dan wujud perilaku umat Islam yang sudah melaksanakan ibadah Haji. Beliau menjelaskan secara mendetail dalam penelitiannya tentang makna ibadah haji beserta proses yang ada didalamnya sebagai satu ritual ibadah yang satu dan dilakukan oleh semua orang yang berhaji tanpa memandang ras, jenis kelamin, kebangsaan, status sosial dan hal-hal lain yang bersifat duniawi, atau dengan kata lain William membuka lebih dalam makna yang terkandung dalam ibadah Haji.

\footnotetext{
${ }^{17}$ Dr. Mochtar Husein, "Hakikat Islam: Sebuah Pengantar Meraih Islam Kaffah", (Yogyakarta: Pustaka Pelajar, 2008), hlm. 165.
} 
Artikel William ini juga bisa dijadikan acuan oleh peneliti dan sejarawan, khususnya dalam kajian keislaman untuk mengkaji Islam lebih dalam dengan metode-metode yang sesuai.

\section{SIMPULAN.}

Kesimpulan dari artikel ini adalah mengenai 3 macam tahapan ritual ibadah haji sebagai berikut:

1. Calon haji melakukan ritual pra-pelaksanaan. Ritual tersebut mencakup pelunasan hutang, pertaubatan dari dosa, bermaaf-maafan dengan sanak saudara, keluarga, teman dan tetangga serta selalu mengingat kematian dengan meninggalkan wasiat kepada keluarga. Ritual ini dikenal dengan tasyakuran atau hurmat haji di Jawa Tengah.

2. Ritual pelaksanaan, yang mencakup semua proses ibadah haji, seperti: Miqat, memakai pakaian ihram, bercukur dan memotong kuku, tawaf, sa'i, wukuf, mabit dan melempar jumrah, sebagai wujud ketaatannya kepada Allah. Ritual ini melibatkan emosi, yaitu rasa kebersamaan sebagai suatu komunitas jamaah haji tanpa memandang ras, status sosial dan hal-hal yang bersifat duniawi. Selain itu, pada tahapan pelaksanaan ini manusia dengan mantap hati bersedia menanggalkan pikirannya hanya untuk berfokus ibadah yang khusyu' kepada Allah SWT.

3. Ritual pasca-pelaksanaan, yang ditandai dengan pulangnya jamaah haji ke tempat asalnya dengan membawa jati diri yang baru, sifat yang santun dan kesalehannya, yang kemudian menjadikan mereka salah satu manusia yang disebut Haji Mabrur. Dalam kehidupannya, orang yang sudah melaksanakan ibadah haji memiliki perilaku yang lebih baik dan santun, tidak berkata buruk dan hanya membawa kebiasaan baik yang biasa ia lakukan di tanah suci.

Selanjutnya, William R. Roff juga mengemukakan bahwa orang yang sudah berhaji menjadi milik komunitas Muslim yang luas maupun masyarakat nasional dan lokal, masyarakat di desa yang semula. Karena yang sudah berhaji membawa jati diri mereka yang baru, yaitu manusia yang berubah menjadi lebih baik dalam hal persepsinya mengenai Islam dan kaum Muslim dan selalu menyadari bahwa tujuannya kembali ke masyarakat adalah menjadi penghubung diantara mereka dalam menciptakan keharmonisan dan kedamaian. 
Haji dilakukan hanya karena Allah semata. Haji harus betul-betul dilakukan dengan niat dan motivasi yang murni, 100\% karena Allah. Haji juga dimaksudkan untuk meyakinkan kembali monoteisme absolut (tauhid murni) yang dicontohkan oleh Ibrahim a.s.

Tujuan utama haji adalah meniru tauhid Ibrahim yang murni, yang akibatnya lahirlah ma'rifatullah yang benar, mengakui eksistensi manusia sebagai hamba, yang dicerminkan dalam pakaian ihram, yang warnanya putih bersih laksana kain kafan, sebagai simbol bahwa manusia akan kembali kepada Tuhan.

\section{UCAPAN TERIMAKASIH}

Dalam penyelesaian artikel ini, penulis mengucapkan banyak terimakasih kepada temanteman di kelas Ilmu Bahasa Arab UIN Sunan Kalijaga yang sudah membantu penyelesaian artikel dengan member banyak masukan yang positif.

Dan terimakasih juga kepada para dosen yang sudah memberi masukan untuk menulis artikel yang baik dan member kontribusi dalam dunia keilmuan.

\section{DAFTAR PUSTAKA}

Al Ghazali, Abu Hamid. Rahasia Haji dan Umroh. 1999. Bandung: Karisma.

Baidhawy, Zakiyuddin. Islamic Studies: Pendekatan dan Metode (pdf). 2011. Yogyakarta: Insan Madani.

Hawwa, Said. Al Islam, Diterjemahkan oleh Abu Ridho dan Aunur Rafiq Shaleh Tamhid. 2012. Jakarta: Al-I'tishom Cahaya Umat

Husein, Mochtar. Hakikat Islam: Sebuah Pengantar Menuju Islam Kaffah. 2008. Yogyakarta: Pustaka Pelajar.

R. Roff, William. Haji dan Sejarah Agama-Agama dalam Richard C. Martin, Pendekatan Terhadap Islam dalam Studi Agama. 2010. Yogyakarta: Suka Press.

Sholikhin, Muhammad. Keajaiban Haji dan Umrah: Mengungkap Kedahsyatan Pesona Ka'bah dan Tanah Suci. 2013. Jakarta: Erlangga.

Syari’ati, Ali. Menjadi Manusia Haji. 2003. Yogyakarta: Jalasutra. 